\title{
Grazing patterns on signalgrass pasture according to location of cattle feces
}

\author{
Manoel Eduardo Rozalino Santos ${ }^{1}$, Dilermando Miranda da Fonseca ${ }^{2}$, Virgílio Mesquita \\ Gomes $^{1}$, Thiago Gomes dos Santos Braz ${ }^{1}$, Simone Pedro da Silva ${ }^{3}$, Ronan Lopes Albino ${ }^{4}$, \\ Andreza Luzia Santos ${ }^{4}$, Guilherme Portes Silva ${ }^{5}$
}

\footnotetext{
1 Programa de Doutorado em Zootecnia - Universidade Federal de Viçosa.

2 Departamento de Zootecnia - Universidade Federal de Viçosa.

3 Programa de Mestrado em Zootecnia - Universidade Federal de Viçosa.

${ }^{4}$ Curso de Graduação em Zootecnia - Universidade Federal de Viçosa.

${ }^{5}$ Curso de Graduação em Agronomia - Universidade Federal de Viçosa.
}

\begin{abstract}
This study was conducted to evaluate the defoliation patterns on B. decumbens cv. Basilisk (signalgrass) tiller as a function of influence of feces deposited naturally by cattle. The signalgrass was managed with an average height of $25 \mathrm{~cm}$, under continuous stocking and variable stocking rate. Interval and intensity of defoliation, grazing efficiency and forage loss were evaluated in two sites on pasture - one close and the other distant from feces. The completely randomized block design with three replications was adopted. The defoliation rate of the pasture site close to feces was $40 \%$ lower than at that distant from feces. This response pattern was similar to defoliation intensity of leaf blade. The leaf blade of the tiller close to feces also achieved lower de foliation (1.64) than that in the tiller distant from feces (3.97). The relative number of grazed leaf per tiller in the tillers distant from feces was approximately $185 \%$ higher than those close to feces. The grazing efficiency was lower in the local close to feces compared with that distant, unlike forage loss. The natural deposition of feces by cattle modifies the grazing and use patterns of $B$. decumbens under continuous stocking.
\end{abstract}

Key Words: Brachiaria decumbens, grazing, sward structure, tiller

\section{Introduction}

The efforts made for the understanding of the aspects relative to the plant/animal interface have assumed importance in the planning of management practices that optimize animal production on pastures (Gonçalves, 2002). In this context, the study of the patterns of tiller defoliation is relevant, for it allows knowing the effects of several environmental factors on the frequency, the intensity and the efficiency of grazing.

Among the factors that affect forage plant defoliation, the natural deposition of feces by ruminants on the pasture stands out. The presence of feces, in addition to increasing the availability of nutrients in the soil (Marchesin, 2005), also results in rejection of plants around them by cattle (Nolan et al., 1986; Willians \& Haynes, 1995). For so, feces may modify the pattern of tiller defoliation, and, consequently, alter the structure of the pasture, which reflects directly on the primary and secondary productivity of ecosystems of pastures (Carvalho et al., 2001).

Pasture defoliation concerning cattle feces can be studied by the frequency and intensity of grazing of its tillers. The intensity of defoliation indicates the percentage of plant tissue that is removed by grazing; and the frequency of defoliation is the number of defoliations that a leaf or tiller goes under in a period of time (Hodgson, 1990).

However, information on the frequency of defoliation of tropical forage grasses is little because, in most of the research studies, a pre-established defoliation interval is adopted (Gonçalves, 2002). Similarly, in the majority of the national experiments, the intensity of grazing consisted of the sum of the intensities of all the defoliations the tiller went through during the period of grazing, and this does not characterize the individual defoliation events of the tiller (Gonçalves, 2002).

Moreover, in these studies, the factors responsible for the spatial heterogeneity of the vegetation, such as the deposition of animal feces on the pasture on the defoliation patterns of individual tillers, have not been assessed (Gonçalves, 2002; Faria, 2009). This information is important, since it allows us to understand the temporal and spatial dynamics of the variation in the arrangement of the organs from the aerial part of plants on the pasture (Santos et al., 2010a). 
Therefore, the objective of this study was to evaluate the effect of the natural deposition of cattle feces on the defoliation patterns of individual Brachiaria decumbens Stapf. cv. Basilisk tillers managed under continuous stocking with cattle.

\section{Material and Methods}

This research was carried out from November 2007 to May 2008 on a Brachiaria decumbens cv. Basilisk (Stapf.) pasture, established in 1997, with approximately $10,000 \mathrm{~m}^{2}$, pertaining to the Setor de Forragicultura of the Department of Animal Science of Universidade Federal de Viçosa, in

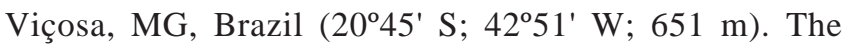
experimental area was composed of three paddocks of about 0.30 ha, in addition to a reserve area. The chemistry analysis of the soil, performed in the beginning of the experimental period, on the $0-20$-cm layer, presented the following results: $\mathrm{pH}$ in $\mathrm{H}_{2} \mathrm{O}$ : 5.4; $\mathrm{P}$ : 1.5 (Mehlich-1) and $\mathrm{K}$ : $88 \mathrm{mg} / \mathrm{dm}^{3} ; \mathrm{Ca}^{2+}: 1.88 ; \mathrm{Mg}^{2+}: 0.47$ and $\mathrm{Al}^{3+}: 0.16 \mathrm{cmol}_{\mathrm{c}} / \mathrm{dm}^{3}$ $(\mathrm{KCl} 1 \mathrm{~mol} / \mathrm{L})$. During the period of evaluation, climatic data were registered at a weather station approximately $500 \mathrm{~m}$ away from the experimental area (Table 1).

Phosphate fertilizer was applied on January 16, 2008, with coverage application of $70 \mathrm{~kg} / \mathrm{ha} \mathrm{P}_{2} \mathrm{O}_{5}$ in the form of single superphosphate, in all the experimental area. Nitrogen fertilization, in the form of urea and on coverage, was performed in three applications of $50 \mathrm{~kg} / \mathrm{ha} \mathrm{N}$ in early evening of each application date (1/16/2008, 2/26/2008 and 4/7/2008).

From November 2007, the paddocks were managed under continuous stocking, with stocking rate variable in order to keep pasture height at about $25 \mathrm{~cm}$. For so, twice weekly, the monitoring of pastures height was done via measurements at 50 points of every paddock, with the aid of instrument made with two PVC tubes, one inside the other (Santos et al., 2011). The internal tube had scale graduated in centimeters and metallic fixed stick (nail) which slid through a crack on the external tube. The criterion for mensuration of pasture height corresponded to the distance from the soil surface to the leaves on the upper part of the canopy. Male Holstein $\times$ Zebu cattle of average weight $200 \mathrm{~kg}$, at the growing phase, were used.

Two areas on the pasture were evaluated: one close to and another distant from the feces. "Close" would mean specifically the area adjacent to the feces, and which encompassed a radius of up to $10 \mathrm{~cm}$ from them. The "distant" area was considered as the sites on the pasture where, in a radius of about $1 \mathrm{~m}$, there was no sign of feces. Completely randomized blocks design with three repetitions was adopted. Due to the differences of relief, each paddock corresponded to a block, where areas close and distant from the feces were identified.

In the beginning of January 2008, signalgrass pasture was infested by Mocis latipes caterpillar, which disabled the fulfillment and continuity of evaluations on field, which had started in mid-December 2007, inasmuch as the animals were removed from paddocks for application of pyrethroids group insecticide (Decis 25EC) at a dose of $200 \mathrm{~mL} / \mathrm{ha}$. Paddocks were once again utilized, under stocking following the previous management, from mid-February 2008 and performing evaluations on the signalgrass in the period from March to May 2008.

Along with the morphogenesis evaluations (Santos et al., 2011) and pasture structure (Santos et al., 2010b), tiller defoliation patterns were assessed in sites of the pasture that initially represented average condition, i.e., target height of $25 \mathrm{~cm}$. In the beginning of these evaluations, areas close to fresh feces were chosen, and probably, they had been recently placed on the pasture, in addition to areas distant from feces. On each paddock, 16 tillers were marked by means of colored plastic rings: eight were close to the signs of feces, and the rest, distant. Two data collection cycles of at least four weeks were evaluated. At each cycle, a new group of tillers was chosen for evaluation.

With the aid of graduated scale, measurements of the length of leaf blades from the tagged tillers were performed, twice weekly. The length of expanded leaves was measured

Table 1 - Monthly means of average air temperature, sun exposure, total monthly rainfall and total monthly evaporation in the period from November 2007 to May 2008 in Viçosa, MG

\begin{tabular}{|c|c|c|c|c|}
\hline Month & Average air temperature $\left({ }^{\circ} \mathrm{C}\right)$ & Sun exposure (hours/day) & Rainfall (mm) & Evaporation (mm) \\
\hline November/2007 & 21.9 & 8.9 & 52.6 & 87.7 \\
\hline December/2007 & 22.9 & 10.7 & 175.7 & 92.4 \\
\hline January/2008 & 21.6 & 8.2 & 219.5 & 434.6 \\
\hline February/2008 & 22.7 & 8.5 & 112.7 & 67.1 \\
\hline March/2008 & 22.0 & 6.1 & 239.2 & 67.8 \\
\hline April/2008 & 21.5 & 6.4 & 62.6 & 55.5 \\
\hline May/2008 & 17.8 & 7.4 & 4.6 & 66.2 \\
\hline
\end{tabular}


from the tip of the leaf blade to its ligule. In the case of expanding leaves, the same procedure was adopted; however, the ligule of the last expanded leaf was adopted as mensuration reference. The number of leaves grazed per tiller was also recorded. From these pieces of information, the following variables were calculated:

Number of leaves grazed per tiller: average number of leaves per tiller with partial or total removal of the leaf blade, in percentage of the total number of live leaves per tiller;

Defoliation intensity (DIn): ratio between the grazed length and the initial length of the expanded leaf blades, expressed in percentage and obtained by the equation: DIn $=($ ILLB - LAD $) /$ ILLB , in which ILLB = initial length of the leaf blade and $\mathrm{LAD}$ = length after defoliation;

Defoliation frequency (DFq): number of defoliations that occurred on the expanded leaf blades during the period of tiller evaluation, obtained by the equation: $\mathrm{DFq}=\mathrm{ND} / \mathrm{DAY}$, in which $\mathrm{ND}=$ number o defoliations, $\mathrm{DAY}=$ number of days of evaluation of the tiller tagged;

Defoliation interval: inverse of the defoliation frequency;

Possible number of defoliations: product of longevity of the leaf and frequency of defoliation. The data concerning leaf lifespan were obtained from the study of Santos et al. (2011), performed concomitantly on the same experimental area;

Grazing efficiency: indicates the percentage of the leaf blade produced which was effectively consumed by the animals, obtained according to Gonçalves (2002);

Forage loss: subtraction of the value of grazing efficiency of $100 \%$.

Pasture height was measured at 50 points per paddock, by choosing randomly 25 points adjacent to the feces signs and 25 ones distant from them. For so, a graduated scale was used.

For visualization of the spatial variation of the vegetation on the pasture, graphs of the relative sequence of the constant intervals on the three paddocks of the experimental area were used. In order to do so, 50 constant means of plants height on every paddock were recorded during the procedures of control of the average height of pastures. Further, these constant intervals of heights were stratified in the following classes: up to $9.9 \mathrm{~cm}$; from 10.0 to $19.9 \mathrm{~cm}$; from 20.0 to $29.9 \mathrm{~cm}$; and from 30.0 to $39.9 \mathrm{~cm}$; from 40.0 to $50.0 \mathrm{~cm}$

Analyses of the experimental data were carried out through the SAEG (Sistema de Análises Estatísticas e Genéticas, version 8.1). For every characteristic, analysis of variance and application of the $\mathrm{F}$ test at up to $10 \%$ probability level were performed.

\section{Results and Discussion}

During the experimental period, the average stocking rate in the paddocks corresponded to $3.7 \mathrm{UA} / \mathrm{ha}$, a value that can be considered high for pastures of Brachiaria decumbens. In general, the stocking rate implies greater natural deposition of feces on the pasture, which can determine more spatial heterogeneity of the vegetation, since cattle reject forage close to feces (Nolan et al., 1986), and the latter also stimulate the growth of the forage plant (Marchesin, 2005; Santos et al., 2011). These factors determined the greater height $(\mathrm{P}<0.10)$ of signalgrass in the locals near the feces $(35 \mathrm{~cm})$ in comparison with the distant sites $(22 \mathrm{~cm})$.

The greater height of plants near the feces contributed to the high coefficient of variation (29\%) of the constant intervals of pasture height, which indicates the inherent spatial variability of the pasture vegetation. The spatial variability of the heights of plants on signalgrass pasture was also expressed by the relative frequency of their values, grouped in classes (Figure 1).

Based on the height value of plants close to the feces $(35 \mathrm{~cm})$ and on the values of relative frequency of plants on pasture (Figure 1), it is possible to infer that the areas close to the feces signs had little participation in the pasture. In fact, class 4 , whose average of the values of plant height $(35 \mathrm{~cm})$ was similar to the height of plants close to the feces, had $8 \%$ relative participation in the pasture. This might have occurred due to the distribution of feces by cattle on the pasture being heterogeneous and related in a more marked way to the idle and rumination acts, which occur at a small area of the pasture (Braz et al., 2003).

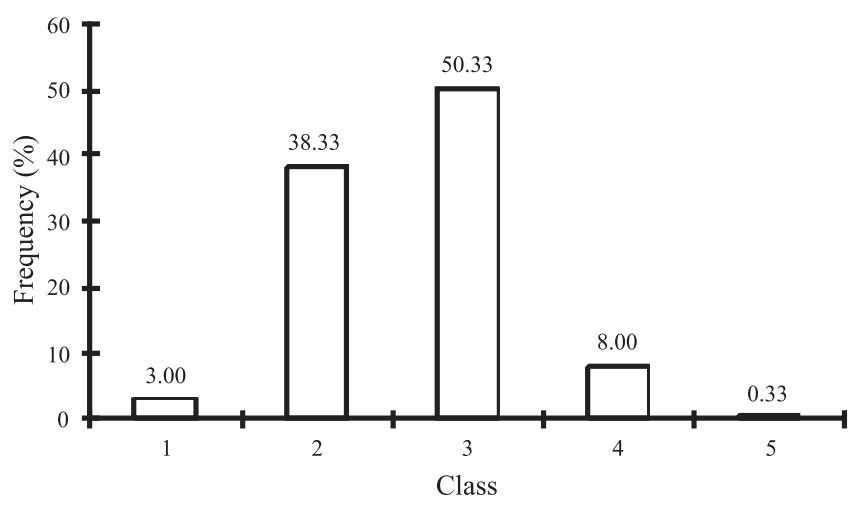

Height classes: $1=$ up to $9.9 \mathrm{~cm}$; $2=$ from 10.0 to $19.9 \mathrm{~cm}$; $3=$ from 20.0 to $29.9 \mathrm{~cm} ; 4$ = from 30.0 to $39.9 \mathrm{~cm} ; 5$ = from 40.0 to $50.0 \mathrm{~cm}$

Figure 1 - Frequency of height values of the plant on signalgrass pasture managed under continuous stocking, with cattle, and average height of $25 \mathrm{~cm}$, from March to April 2008. 
In spite of the occurrence in restricted areas of the pasture, feces altered the defoliation pattern of plants. In this sense, the frequency of defoliation was $40 \%$ lower $(\mathrm{P}<0.05)$ at the local of pasture near the feces, in relation to the distant site (Figure 2A). This result was because cattle reject the forage in pasture sites close to feces (Willians \& Haynes, 1995), due to their odor (Nolan et al., 1986), which tends to be more accented right after their release on the pasture.

Furthermore, the rejection of forage by cattle might have occurred, in a later moment, due to the more advanced development stage of the plant near the feces. Such plants usually present higher growth rates (Santos et al., 2011) because of the greater availability of nutrients in the soil, originated from the mineralization of fecal organic matter. This fact, coupled with the initial rejection by the animals, results in plants with morphological composition characterized by low leaf/stem ratio and high percentage of senescent tissue. The accumulation of dead tissue and stem may contribute to the rejection of pasture by animals (Jacques, 1974).

On the other hand, at the local distant from the feces, the absence of odor in the excreta, as well as the maintenance of the pasture with structure more suitable for animal consumption, can explain the higher defoliation rate on tillers of signalgrass (Figure 2A). When compared with the sites close to the feces, the structure of the pasture in the local distant from them was characterized by lower stem mass, lower number of reproductive tillers and higher number of vegetative tillers of smaller size (Santos et al., 2011, 2010b), which is indicative of better nutritive value (Santos et al., 2010c). These attributes may imply that the placement of the organs in the aerial part of the signalgrass at the local distant from feces was a predisposing factor to the consumption of cattle, which explains their higher defoliation rate.

Since the inverse of the defoliation rate corresponds to the interval of defoliation, it is natural that the result of the latter be opposite to the one obtained for the defoliation rate (Figure 2B). In fact, the interval of defoliation at the local distant from feces was approximately three times lower $(\mathrm{P}<0.05)$ than at the site close to feces. Willians \& Haynes (1995) reported that the area of the pasture rejected by animals can be 5 to 12 times bigger than the area of the pasture with feces, and the period for this rejection may range from 40 days to 18 months, according to the soil and climate conditions.

As for the intensity of defoliation of leaf blades, it could be observed that the value was superior at the local distant from the feces, when compared with that close to feces (Figure 3). This answer pattern may have been due to the shorter length of the leaf blades of tillers on sites distant from feces, in relation to those close to feces (Santos et al., 2011). Therefore, when the animal performed the bite, the removal of certain length of the leaf blade resulted, relatively, in greater defoliation intensity for the leaves of shorter length, and the opposite occurred in leaf blades of longer length, present on the tillers located near the feces.

It is also possible that cattle compensated the lower pasture height on the local distant from feces (Santos et al., 2010b), which limits the depth of the bite (Hodgson, 1990), with bites closer to the soil level. Thus, the defoliation intensity was greater (Figure 3). Gonçalves (2002) evaluated the effect of four mean heights of Marandu palisadegrass managed under continuous stocking and observed higher values of defoliation intensity on the pasture kept lower $(10 \mathrm{~cm})$ in relation to the taller ones $(20,30$ and $40 \mathrm{~cm})$.

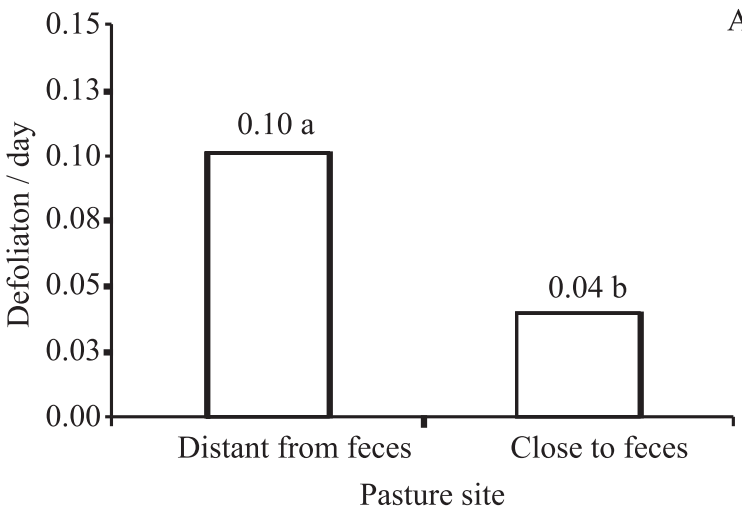

A

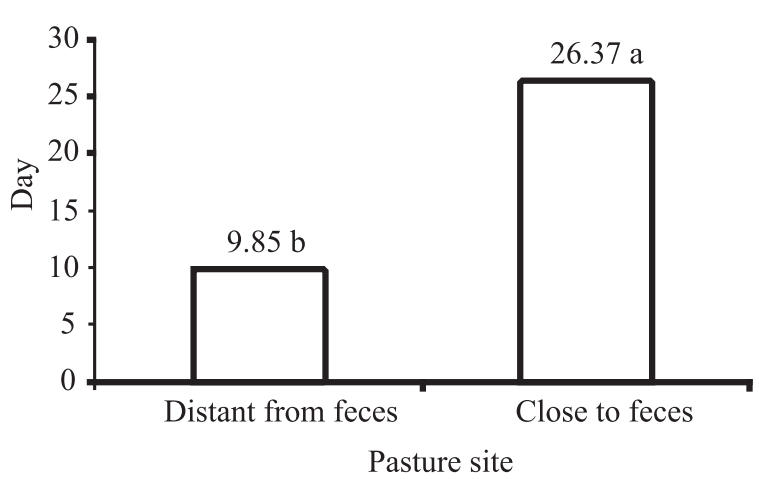

Figure 2 - Defoliation frequency (A) and defoliation interval (B) of leaf blades on B. decumbens cv. Basilisk according to the proximity to feces and cattle. For each characteristic, means followed by different letters differ $(\mathrm{P}<0.10)$ by $\mathrm{F}$ test. 
One must consider, yet, that the lower defoliation intensity of the tillers close to feces might be related to the greater blooming of these tillers, which increases the participation of the stem on the pasture. The longer length of the stem on the reproductive tiller (Santos et al., 2010d) limits the depth of pasture and the defoliation intensity of tillers, for the stem presents better resistance to shearing (Nave et al., 2010).

Based on the longevity of the leaf blade and the defoliation rate (Figure 2A), it was possible to estimate the number of defoliations occurring on the leaf blade throughout the leaf lifespan. Hence, it was observed that the leaf blade of tillers close to feces did not reach two defoliations, presenting value $(\mathrm{P}<0.05)$ inferior to that observed for the leaf blade on the tiller distant from feces, which was grazed about four times while alive (Figure 4).

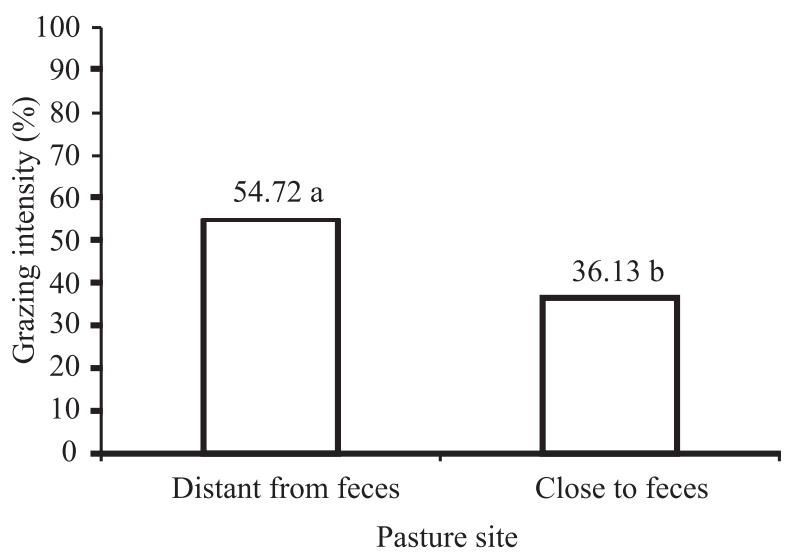

Figure 3 - Defoliation intensity of leaf blades on B. decumbens $\mathrm{cv}$. Basilisk according to proximity to feces and cattle. Means followed by different letters differ $(\mathrm{P}<0.10)$ by $\mathrm{F}$ test.

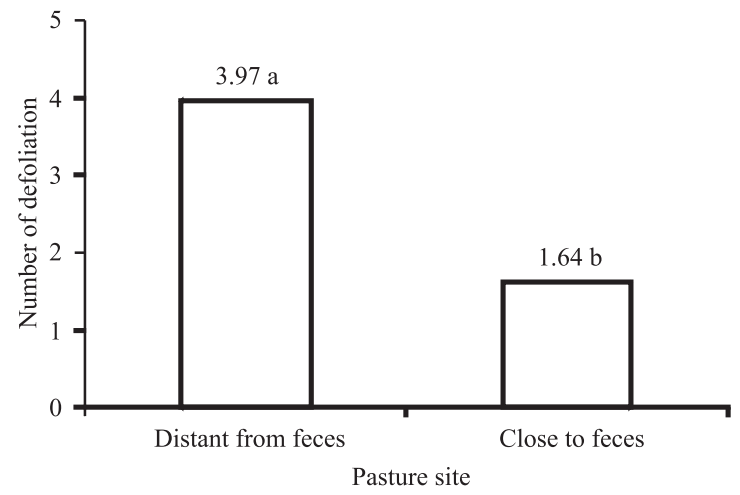

Figure 4 - Calculated number of defoliations on B. decumbens cv. Basilisk leaf blades according to proximity to feces and cattle. Means followed by different letters differ $(\mathrm{P}<0.10)$ by $\mathrm{F}$ test.
In comparison with the site close to feces, the greater number of defoliations on the leaf blade distant from feces occurred because at this site of the pasture, the defoliation rate was also superior (Figure 2A), whereas the leaf lifespan was not affected by the presence of feces, and presented mean value of 38 days (Santos et al., 2011). Based on this result, one can infer that the loss of leaf tissue by senescence tends to be lower in the tillers located distant from feces, inasmuch as all the leaf blade synthesized and which is not harvested winds up senescent after the end of its lifespan (Hodgson, 1990), which may be observed by the number of dead leaves, which was superior (2.8) in the tiller close to feces, in relation to that distant (1.9; Santos et al., 2011).

The greater number of defoliations on plants located distant from feces modifies the sward structure. Santos et al. (2010e) evaluated the characteristics of tillers at three sites of the same $B$. decumbens pasture and verified that, in the local with overgrazing, characterized by the presence of plants with height inferior to $50 \%$ of the average pasture height, tillers had shorter stem and leaf blade length, smaller number of dead leaf and masses of live stem and live leaf blade.

The different defoliation pattern of the sites close to and distant from feces also originates the spatial variability of the vegetation, characterizing the horizontal structure of the monospecific pasture of signalgrass. Accordingly, Santos et al. (2010a) quantified different height class of plants on the same $B$. decumbens pasture under continuous stocking, which may have been, among other factors, a consequence of the irregular distribution of feces on the pasture (Braz et al., 2003). In fact, the existing vegetation on a pasture is, inherently, spatially heterogeneous (Barthram et al., 2005).

The relative number of leaf blades grazed per tiller was approximately $185 \%$ superior $(\mathrm{P}<0.05)$ at those tillers located distant from feces than those close (Figure 5). This occurred due to the shorter defoliation interval of the leaf blades distant from feces (Figure 2B), as explained previously.

The greater defoliation on tillers distant from feces was compensated by morphological adaptations of signalgrass. Santos et al. (2011) verified higher rates of leaf appearance, higher population density of tillers in vegetative growth stage, as well as shorter stem and leaf blades length on tillers located distant from feces. Such adaptations characterize the phenotypic plasticity of signalgrass and are important for the plant to optimize its capacity of light interception (Lemaire, 2001) and to increase the carbon balance of the tiller (Parsons et al., 1983). 
The specific defoliation patterns by cattle in the pasture sites evaluated determined modifications in grazing efficiency, which was greater $(\mathrm{P}<0.05)$ at the site distant from feces in relation to that close (Figure 6A). The rejection of forage by cattle in the areas close to feces, plus the effect of deposition of feces on the improvement of soil fertility conditions (Braz et al., 2002), which favor pasture growth (Marchesin, 2005) explain this result. These factors result in smaller removal of vegetal tissue, which are usually produced in a larger scale at the site close to feces, which decreases pasture efficiency, and, therefore, increases forage loss.

Forage loss was superior $(\mathrm{P}<0.05)$ at the local close to feces in relation to that distant (Figure 6B). The leaves of tillers close to feces had fewer opportunities to be defoliated

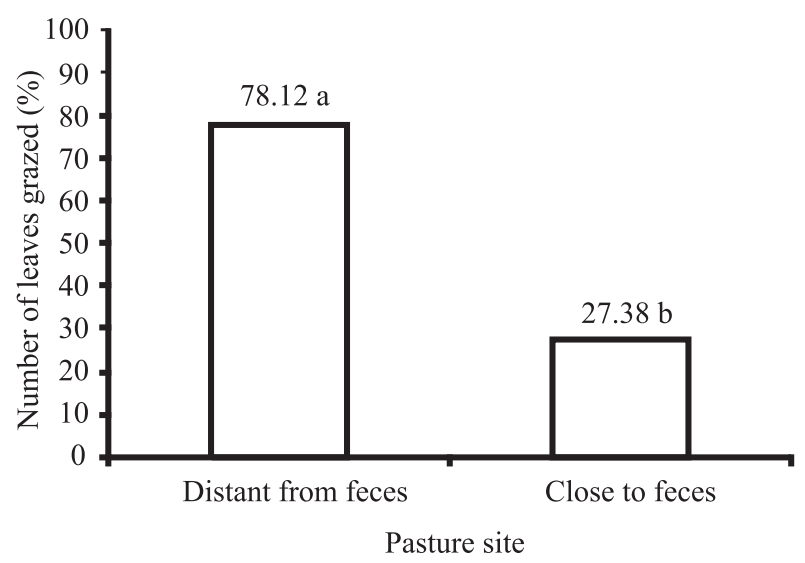

Figure 5 - Percentage number of leaf blades grazed per tiller of B. decumbens cv. Basilisk with proximity to feces and cattle. Means followed by different letters differ $(\mathrm{P}<0.10)$ by the $\mathrm{F}$ test. throughout their lifespan (Figure 4), contributing to the losses by senescence and low usage of the forage produced (Figure 6).

In spite of the benefits to the forage plant from the availability of part of the nutrients contained in the feces via mineralization of organic matter (Braz et al., 2002), the results presented enable inferring that the deposition of feces by cattle damages one of the production stages of the grazing animal: the utilization of the forage produced.

Among the strategies of management that allow reduction of forage loss during grazing due to the deposition of feces by cattle is mixed grazing, which consists of the employment of more than one species of herbivore grazing on the same forage resource, which can occur simultaneously or in successive periods (Carvalho \& Rodrigues, 1997). In this sense, mixed pasture, with cattle and sheep, would increase efficiency at pasture usage, since sheep consume great part of the forage rejected by cattle in the areas of natural deposition of feces (Nolan, 1986).

It is important to remark that the deposition of feces represents return to the soil by the nutrients absorbed by the plant and ingested by the animal, which characterizes the external nutrient cycling in the pasture ecosystem (Braz et al., 2002). In addition to this, the presence of feces on pasture also favors the internal nutrient cycling in the forage plant, since, with rejection of the forage close to feces by cattle, there is greater leaf senescence (Santos et al., 2011) and, in this process, part of the minerals, such as nitrogen, is recycled internally in the plant (Lemaire, 2001).

In most of the national research studies, in which the defoliation patterns in individual tillers were assessed, the results were expressed only in relation to the tillers located at the sites that represented the average condition of pastures (Gonçalves, 2002; Faria, 2009). Therefore, the
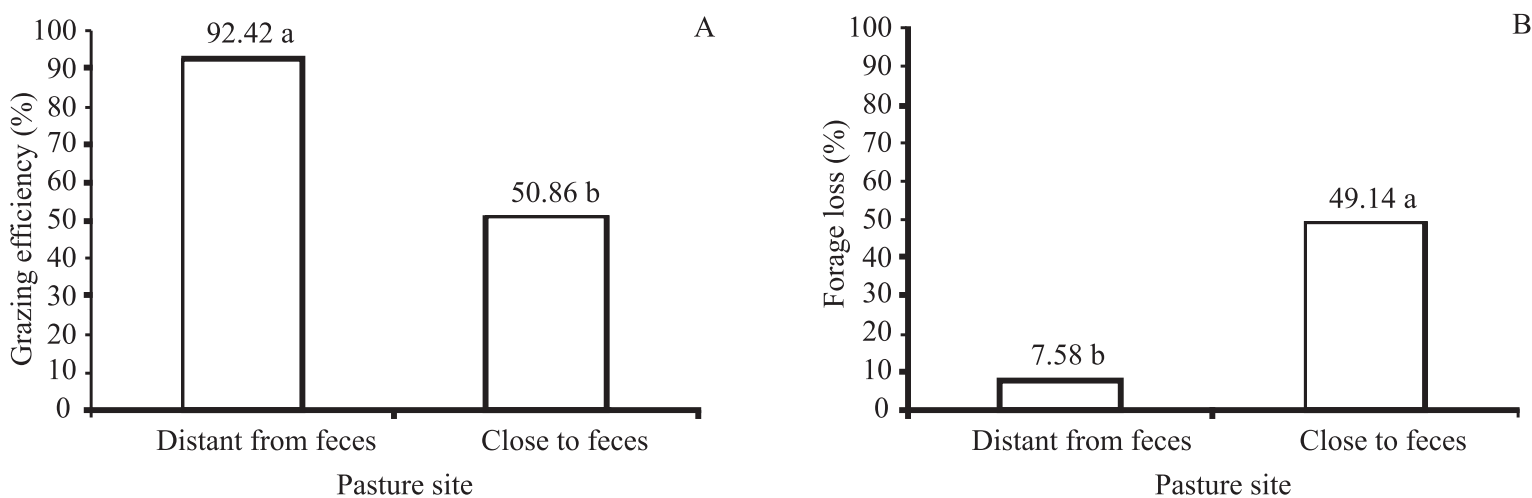

Figure 6 - Grazing efficiency (A) and forage loss (B) on B. decumbens cv. Basilisk pasture according to proximity to feces and cattle. For each characteristic, means followed by different letters differ $(\mathrm{P}<0.10)$ by $\mathrm{F}$ test. 
other locals in the same pasture, with deviations in relation to their average condition, were not assessed.

Considering that the pasture is inherently heterogeneous, the information originated from the locals representative of the average pasture condition may not appropriately represent the processes (growth, senescence, defoliation, etc) that occur in the forage plant community, especially in those very heterogeneous. This would compromise the utilization of this information as basis for the proposal of forage plants management strategies. However, more study is necessary, with regards to test this hypothesis, a well as to understand the factors that cause the spatial heterogeneity of the vegetation.

\section{Conclusions}

The natural deposition of feces by cattle modifies the patterns of defoliation and utilization of $B$. decumbens cv. Basilisk managed under continuous stocking, which contributes to the generation of spatial variability of the vegetation.

\section{References}

BARTHRAM, E.; DUFF, G.T.I.; ELSTON, D.A. et al. Frequency distributions of sward height under sheep grazing. Grass and Forage Science, v.60, p.4-16, 2005.

BRAZ, S.P.; NASCIMENTO JÚNIOR, D.; CANTARUTTI, R.B. et al. Aspectos quantitativos do processo de reciclagem de nutrientes pelas fezes de bovinos sob pastejo em pastagem de Brachiaria decumbens na Zona da Mata de Minas Gerais. Revista Brasileira de Zootecnia, v.31, n.2, p.858-865, 2002 (supl.).

BRAZ, S.P.; NASCIMENTO JÚNIOR, D.; CANTARUTTI, R.B. et al. Caracterização da distribuição espacial das fezes por bovinos em uma pastagem de Brachiaria decumbens. Revista Brasileira de Zootecnia, v.32, n.4, p.787-794, 2003.

CARVALHO, P.C.F.; RIBEIRO FILHO, H.M.N.; POLI, C.H.E.C. et al. Importância da estrutura da pastagem na ingestão e seleção de dietas pelo animal em pastejo. In: REUNIÃO ANUAL DA SOCIEDADE BRASILEIRA DE ZOOTECNIA, 38., 2001, Piracicaba. Anais... Piracicaba: ESALQ, 2001. p.883-871.

CARVALHO, P.C.F.; RODRIGUES, L.R.A. Potencial de exploração integrada de bovinos e outras espécies para utilização intensiva de pastagens. In: SIMPÓSIO SOBRE MANEJO DE PASTAGENS: PRODUÇÃO ANIMAL A PASTO, 13., 1997, Piracicaba. Anais... Piracicaba, 1997. p.275-301.

FARIA, D.J.G. Características morfogênicas e estruturais dos pastos e desempenho de novilhos em capim-braquiária sob diferentes alturas. 2009. 145f. Tese (Doutorado em Zootecnia) - Universidade Federal de Viçosa, Viçosa.
GONÇALVES, A.C. Características morfogênicas e padrões de desfolhação em pastos de capim-marandu submetidos a regimes de lotação contínua. 124f. 2002. Dissertação (Mestrado em Agronomia - Ciência Animal e Pastagens) ESALQ, Piracicaba.

HODGSON, J. Grazing management. Science into practice. New York: John Wiley and Sons; Longman Scientific and Technical, 1990. 203p.

JACQUES, W.A. Yorkshire fog (Holcus lanatus L.) It's potential as a pasture species. Proceedings of the New Zealand Grassland Association, v.35, p.249-257, 1974.

LEMAIRE, G. Ecophysiology of grasslands: dynamic aspects of forage plant populations in grazed swards. In: INTERNATIONAL GRASSLAND CONGRESS, 19., 2001, São Pedro. Proceedings... São Pedro: FEALQ, 2001. p.29-37.

MARCHESIN, W.A. Dinâmica de deposição de fezes em pastagem de Brachiaria brizantha submetida à intensidades de pastejo. Pirassununga: Faculdade de Zootecnia e Engenharia de Alimentos, 2005. 63p. Dissertação (Mestrado em Zootecnia) Faculdade de Zootecnia e Engenharia de Alimentos, 2005.

NAVE, R.L.G.; PEDREIRA, C.G.S.; PEDREIRA, B.C. Nutritive value and physical characteristics of Xaraes palisadegrass as affected by grazing strategy. South African Journal of Animal Science, v.40, p.285-293, 2010.

NOLAN, T.; BJARNASON, V.; CONNOLY, J. et al. Animal/pasture relationships under mixed sheep/cattle grazing. In: GENERAL MEETING OF EUROPEAN GRASSLAND FEDERATION ON “GRASSLANDS FACING THE ENERGY CRISIS”, 11., 1986, Portugal. Proceedings... Portugal, 1986. p.481-488.

PARSONS, A.J.; LEAFE, E.L.; COLLET, B. et al. The physiology of grass production under grazing. II. Photosynthesis, crop growth and animal intake of continuously-grazed swards. Journal of Applied Ecology, v.20, p.127-139, 1983.

SANTOS, M.E.R.; FONSECA, D.M.; BALBINO, E.M. et al. Variabilidade espacial e temporal da vegetação em pastos de capim-braquiária diferidos. Revista Brasileira de Zootecnia, v.39, n.4, p.727-735, 2010a.

SANTOS, M.E.R.; FONSECA, D.M.; SILVA, S.P. et al. Características estruturais do pasto de capim-braquiária de acordo com a localização das fezes. Revista Brasileira de Zootecnia, v.39, n.10, p.2116-2124, 2010b.

SANTOS, M.E.R.; FONSECA, D.M.; BALBINO, E.M. et al. Correlações entre características estruturais e valor nutritivo de perfilhos em pastos de capim-braquiária diferidos e adubados com nitrogênio. Revista Brasileira de Saúde e Produção Animal, v.11, n.3, p.595-605, 2010c.

SANTOS, M.E.R.; FONSECA, D.M.; BALBINO, E.M. et al. Características estruturais de perfilhos vegetativos e reprodutivos em pastos diferidos de capim-braquiária. Ciência Animal Brasileira, v.11, n.3, p.492-502, 2010 d.

SANTOS, M.E.R.; FONSECA, D.M.; GOMES, V.M. et al. Caracterização de perfilhos de capim-braquiária em locais do mesmo pasto com três intensidades de pastejo. Revista Brasileira de Saúde e Produção Animal, v.11, n.4, p.961-975, 2010e.

SANTOS, M.E.R.; FONSECA, D.M.; BRAZ, T.G.S. et al. Influência da localização das fezes nas características morfogênicas e estruturais e no acúmulo de forragem em pastos de capimbraquiária. Revista Brasileira de Zootecnia, v.40, n.1, p.31-38, 2011.

WILLIANS, P.H.; HAYNES, R.J. Effect of sheep, deer and cattle dung on herbage production and soil nutrient content. Grass and Forage Science, v.50, p.263-271, 1995. 